\title{
Acupuncture in the treatment of temporomandibular muscle dysfunction
}

\author{
Acupuntura no tratamento da disfunção temporomandibular muscular
}

Evelyn de Freitas Boscaine ${ }^{1}$, Elenir Rose Jardim Cury Pontes ${ }^{1}$, Daisilene Baena Castillo ${ }^{1}$, Lirane da Silva Carneiro Suliano ${ }^{2}$, Nelson Talatoci Oshiro Filho' ${ }^{1}$

DOI 10.5935/2595-0118.20190064

\section{ABSTRACT}

BACKGROUND AND OBJECTIVES: Temporomandibular dysfunction consists of frequent non-dental pain in the orofacial region of multifactorial origin and interdisciplinary treatment, among them, acupuncture. The treatment of temporomandibular dysfunction acts both in muscle relaxation and pain control, trying to achieve the physical, mental, and emotional balance of the patient, thus reducing anxiety and improving the quality of life. The objective of this study was to evaluate acupuncture as a treatment for temporomandibular dysfunction.

METHODS: A total of 34 volunteers screened and selected at the Federal University of Mato Grosso do Sul, diagnosed with muscle dysfunction according to the Research Diagnostic Criteria. They were randomly divided into two equal groups: group 1 treated with occlusal plaque, massage, thermotherapy and selfcare guidelines; and group 2 treated with six acupuncture sessions lasting 30 minutes each. The pain was evaluated by the visual analog scale, and an algometer to assess the muscular tension of the temporal and masseter muscles. The limitation of mouth opening was measured with the use of calipers. The Mann-Whitney test was used for the non-normal distribution (visual analog scale and tension threshold) between the two groups (G1 and G2), and the Friedman test to compare the assessment periods (beginning of the treatment, after six weeks and four months) with a significance level of $5 \%$.

RESULTS: There was no difference in mouth opening, visual analog scale scores, or muscle tension threshold in relation to the type of treatment used. Both groups improved after six weeks of treatment. There was no statistical difference in the values obtained after six weeks and after four months.

Evelyn de Freitas Boscaine - (Dhttps://orcid.org/0000-0001-6469-3916;

Elenir Rose Jardim Cury Pontes - (Dhttps://orcid.org/0000-0003-2711-0667;

Daisilene Baena Castillo - Dhttps://orcid.org/0000-0003-4261-7503;

Lirane da Silva Carneiro Suliano - (Dhttps://orcid.org/0000-0002-1590-0517;

Nelson Talatoci Oshiro Filho - (Dhttps://orcid.org/0000-0002-3632-5929.

1. Universidade Federal de Mato Grosso do Sul, Faculdade de Odontologia, Campo Grande, MS, Brasil.

2. Universidade Federal do Paraná, Curitiba, PR, Brasil.

Submitted on February 13, 2019.

Accepted for publication on October 16, 2019.

Conflict of interests: none - Sponsoring sources: none.

Correspondence to:

Avenida Costa e Silva. S/no - Bairro Universitário

79070-900 Campo Grande, MS, Brasil.

E-mail: evelynboss@hotmail.com

(C) Sociedade Brasileira para o Estudo da Dor
CONCLUSION: The statistical results showed that acupuncture increased the muscle tension threshold, improved the mouth opening and reduced pain, being as effective as the most commonly used conventional therapies.

Keywords: Acupuncture, Orofacial pain, Temporomandibular dysfunction.

\section{RESUMO}

JUSTIFICATIVA E OBJETIVOS: A disfunção temporomandibular consiste em dores não dentárias frequentes na região orofacial, de origem multifatorial e de tratamento interdisciplinar. Entre esses tratamentos está a acupuntura. O tratamento da disfunção temporomandibular atua tanto no relaxamento muscular quanto no controle da dor, sistemicamente buscando o equilíbrio físico, mental e emocional do paciente, diminuindo a ansiedade e melhorando a qualidade de vida. Este trabalho teve como objetivo avaliar a acupuntura como tratamento da disfunção temporomandibular.

MÉTODOS: Participaram do estudo 34 voluntários triados e selecionados na universidade de Mato Grosso do Sul, diagnosticados com disfunção muscular pelo Research Diagnostic Criteria, e foram divididos aleatoriamente em dois grupos iguais. $\mathrm{O}$ grupo 1 foi tratado com placa oclusal, massagem, termoterapia e orientaçóes de autocuidado. O grupo 2 foi tratado com 6 sessóes de acupuntura com duração de 30 minutos cada. A dor foi avaliada pela escala analógica visual e com auxílio de um algômetro para avaliar a tensão muscular dos músculos temporal e masseter. A limitação de abertura bucal foi medida com o uso do paquímetro. Para a distribuição não normal (escala analógica visual e limiar de tensão), entre os dois grupos (G1 e G2), foi utilizado o teste Mann-Whitney, e para a comparação entre os períodos de avaliação (início do tratamento, após seis semanas e 4 meses), foi utilizado o teste de Friedman, ao nível de significância de 5\%.

RESULTADOS: Não houve diferença das medidas de abertura de boca, dos escores de escala analógica visual e de limiar de tensão muscular segundo o tipo de tratamento utilizado. No entanto, em ambos os grupos houve melhora nos parâmetros avaliados após seis semanas de tratamento. Não houve diferença estatística dos valores obtidos após seis semanas e ao final do tratamento, após quatro meses.

CONCLUSÁO: Os resultados estatísticos mostraram que a acupuntura aumentou o limiar de tensão muscular, melhorou a abertura de boca e diminuiu a dor. Concluiu-se que a acupuntura foi tâo eficiente quanto as terapias convencionais mais utilizadas.

Descritores: Acupuntura, Disfunção temporomandibular, Dor orofacial. 


\section{INTRODUCTION}

Temporomandibular dysfunction (TMD) is a set of clinical signs and symptoms involving the masticatory muscles, the temporomandibular joint (TMJ) and associated structures ${ }^{1}$. Currently, TMD is basically divided into two groups, which are joint and muscle dysfunction ${ }^{2}$. Symptoms most frequently reported by patients are muscle fatigue, facial pain, headache, TMJ pain, and chewing muscle pain. Ear pain, mandibular movement limitation, tinnitus may be present in some cases, especially in joint dysfunction ${ }^{3}$.

It is important to know some of the factors that can contribute to the development and maintenance of TMD, such as teeth clenching, bruxism (grinding or clenching), biting foreign objects such as pens or nails, chewing gum, head posture or presenting factors related to stress, depression, and anxiety or traumatic events, malocclusions and occlusal maladjustments, such as missing teeth ${ }^{4-6}$.

Because TMD have a multifactorial etiology, they require an interdisciplinary therapeutic approach through a team of several specialties, or at least close collaboration ${ }^{7}$. The use of interocclusal splints is the most used treatment in dentistry, as they cause local muscle relaxation and relief of muscle pain. Others act presumably more centrally, including acupuncture ${ }^{8-10}$.

The use of occlusal splints comprises a treatment modality with a high success rate in reducing muscle TMD symptoms, but it is only effective when used correctly ${ }^{11-13}$. However, there are still patients who do not respond to treatment with splints, so it is necessary to institute other treatment modalities ${ }^{5,14,16}$. Occlusal splint therapy temporarily reduces muscle hyperactivity through peripheral changes arising from afferent impulse changes in the organic receptors, leading to an efferent response that reduces muscle tension in the region in question. The association of the splint with other treatments has also been widely used. It is necessary to offer the patient a treatment capable of reducing his/her limitations, relieving pain, and discomfort in order to improve his/her quality of life ${ }^{17}$. Acupuncture is considered as a holistic science and therapy that preaches mental and emotional balance through the harmony of the patient's energy flow in the energy channels. Energy channels are webs that run through the body, the internal organs, and viscera (Zang $\mathrm{Fu}$ ) and coincide with the topography of nerve plexuses that control the body's functioning ${ }^{18}$.

Acupuncture, unlike the occlusal splint, acts through the central mechanism of pain inhibition, involving segmental blockage in the spinal cord. This causes the release of neuromodulators, such as endorphins and serotonin, which alter pain sensitivity through the central mechanism of analgesia ${ }^{19}$. Acupuncture has anti-inflammatory, anxiolytic, myorelaxant, and immune function activating effects, being an alternative, integrative, and complementary therapy used to treat TMD. It is based on the principle of uniting, integrating and solidifying all dental technical and scientific knowledge with those of the Traditional Chinese Medicine (TCM), aiming at the best results for the patient, better quality of life, well-being and health ${ }^{20,21}$. Because it is a natural technique and addresses the patient as a whole (physically, mentally, and emotionally), it acts in a noninvasive and reversible manner, both on local and systemic factors, in which the most commonly used therapeutic modalities fail to achieve efficiently. According to TCM, human beings must be viewed and treated in a holistic, integral way, as they have an indivisible physical, mental, emotional origin and are an integral and active part of their physical, natural, and psychosocial environment ${ }^{22-24}$.

Based on the literature, this study aimed to compare the effects of acupuncture on occlusal splint in the treatment of patients with muscle TMD.

\section{METHODS}

Thirty-four individuals were screened in the TMD extension project (SERDOF) of the School of Dentistry (FAODO) of the University of Mato Grosso do Sul, who presented a clinical picture of muscle TMJ pain and dysfunction. After being evaluated by the Research Diagnostic Criteria (RDC/TMD) exam and signing the Free and Informed Consent Term (FICT), the patients participated in the random selection of the research groups.

The sample size was determined with the SPSS software version 24.0 (SPSS, Inc., Chicago, IL, EUA) by the t-test calculation, accepting a sample mean of pain score decrease in the visual analog scale (VAS) after treatment of TMD of $5.29 \pm 0.43$, population mean of 5.0 , significance level of $5 \%$ and power of $80 \%$, resulting in a minimum sample of 17 participants for each group.

The inclusion criteria were being diagnosed with muscle TMD and being over 18 years old. The exclusion criteria were the previous treatment of TMD, have fibromyalgia, pregnant women; individuals using neuromuscular drugs; cancer patients.

The patients were randomized by simple draw into two groups: G1: $\mathrm{n}=17$, who underwent massage treatment, thermotherapy, counseling, and occlusal device. The patients were instructed to use the myorelaxant splint at night (Figure 1).

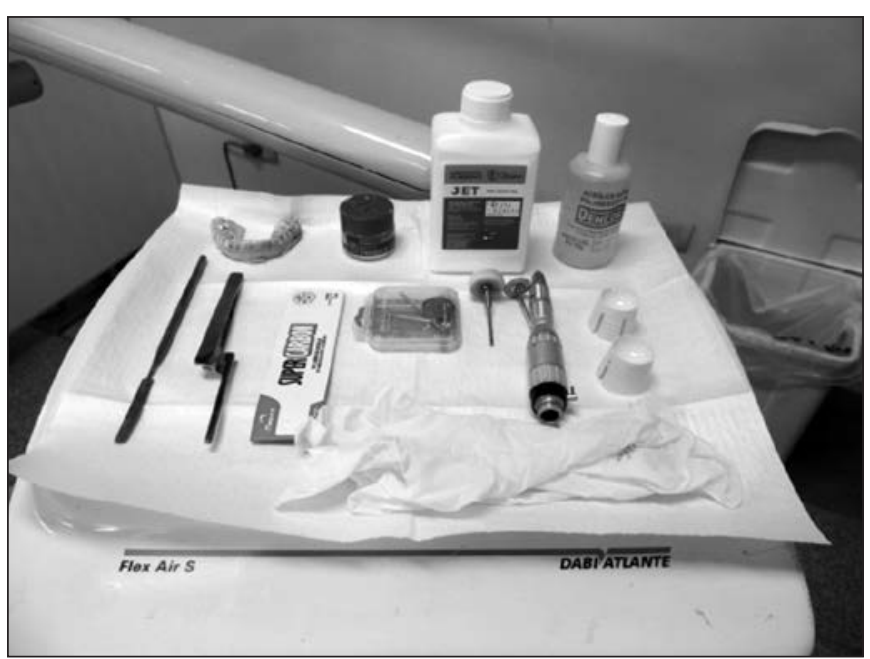

Figure 1. Occlusal splint 
Participants received counseling and self-care guidance. The occlusal splints were of $2 \mathrm{~mm}$ thick acetate from Bio.art brand, and all were reinforced with a mean $2 \mathrm{~mm}$ thick acrylic layer to improve their strength and smoothness. No semi-adjustable articulator was used to make the splints. A single skilled and experienced RDC/TMD professional installed and adjusted the splints, carefully checking the highest number of contact points, and the protrusion and laterality of jaw movements. After the splints were installed, patients were instructed to use only at night and return for follow-up and possible adjustments every 15 days. Patients were reevaluated after six weeks and four months of treatment. G2 ( $\mathrm{n}=17)$ underwent acupuncture sessions once a week for 30 minutes. There were six acupuncture sessions. The treatment was performed with $0.25 \times 15 \mathrm{~mm}$ disposable needles (acupuncture needles) of DongBang Xu li Ltda brand, at points called acupoints. The skin was previously cleansed with $70 \%$ ethyl alcohol by a specialized professional. In each session, the patients remained for 30 minutes lying down and relaxed. The selected points followed the TCM diagnostic protocol. The selected points were:

a) for local pain, stomach meridian E7 (Xianguan); a local meridian point of the stomach that improves ear and TMJ functions, relieves muscle spasm of the masseter, decreases jaw motor imbalance and decreases pain ${ }^{25}$.

b) systemic points: VG20 (Baihui) - governing vessel channel (Figure 2). A systemic point indicated to calm the mind, reduce stress, improve sleep, calm thoughts, soothe the spirit, relax muscles ${ }^{25}$. TA5 (Waiguan) - triple heater channel (Figure 3). Systemic point for the treatment of pain and irritability, treatment of otitis, tinnitus, reduces headache, treatment of neck and shoulder muscle pain ${ }^{25}$. IG4 (Hegu) - large intestine channel (Figure 4). A systemic point that strengthens the immune system, anti-inflammatory point of the upper limbs, analgesia, calms the mind, promotes labor (contraindicated in pregnant women), regulates the stomach and intestine channels, regulates the uterus, treats tinnitus and deafness, treats the flu, sinusitis, rhinitis, anxiety, and neck muscle pain ${ }^{25}$. E36 (Zusanli) - stomach channel (Figure 5). Systemic point regulates the immune system, regulates the intestines, increases energy. According to Chinese belief, this point is the point of vitality, strength, and long life, rebalances the mind, decreases fever, treats depressive disorders ${ }^{25}$. F3 (Taichong) liver channel (Figure 6). A systemic point that regulates menstruation, treats menstrual cramps, calms the mind, treats headaches, treats irritability, treats insomnia, reduces worry, rebalances the mind ${ }^{25}$.

The points are applied bilaterally, except for the central point VG20, totaling 11 points for pain, anxiety, and stress, following the TCM criteria. Patients were reevaluated after six weeks and four months of treatment.

Both groups were evaluated and treated by the same professional, dental surgeon and acupuncture specialist by the Instituto Brasileiro de Técnicas Médicas (IBRATE) and volunteer of SERDOF-DTM (Serviço de Dor Orofacial e Disfunção Temporomandibular) at UFMS.

After the reevaluations, the results were statistically analyzed.

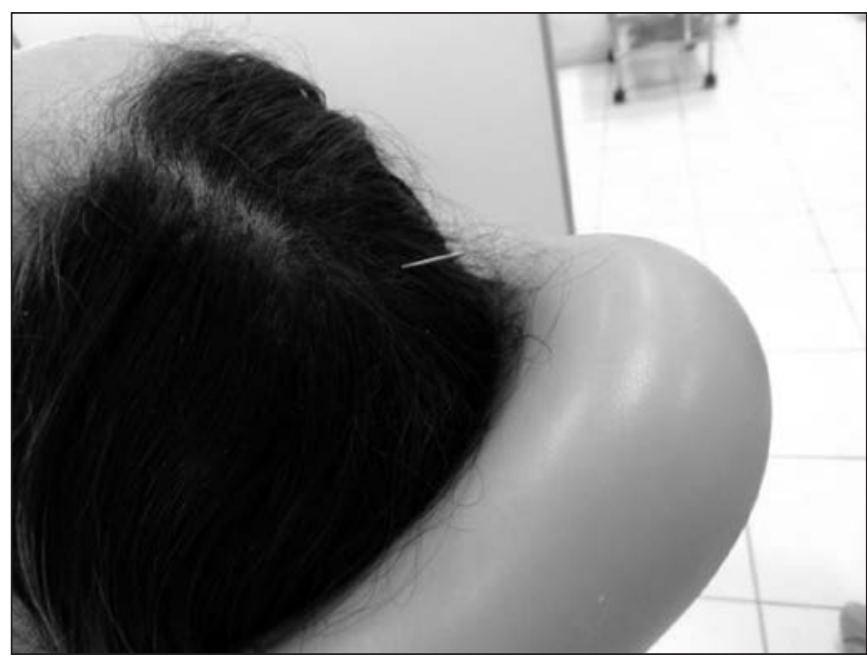

Figure 2. VG20 acupuncture point

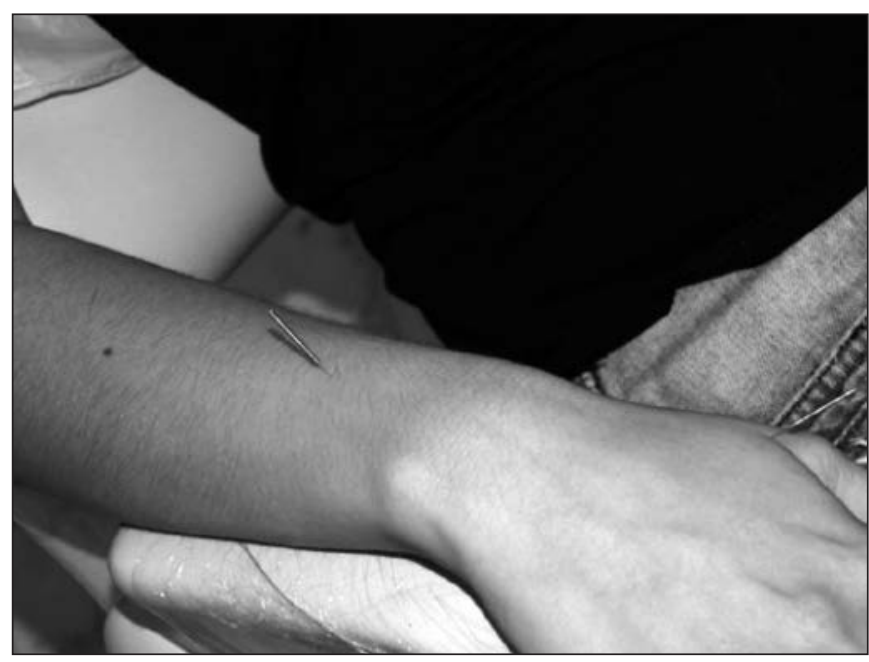

Figure 3. TA5 acupuncture point

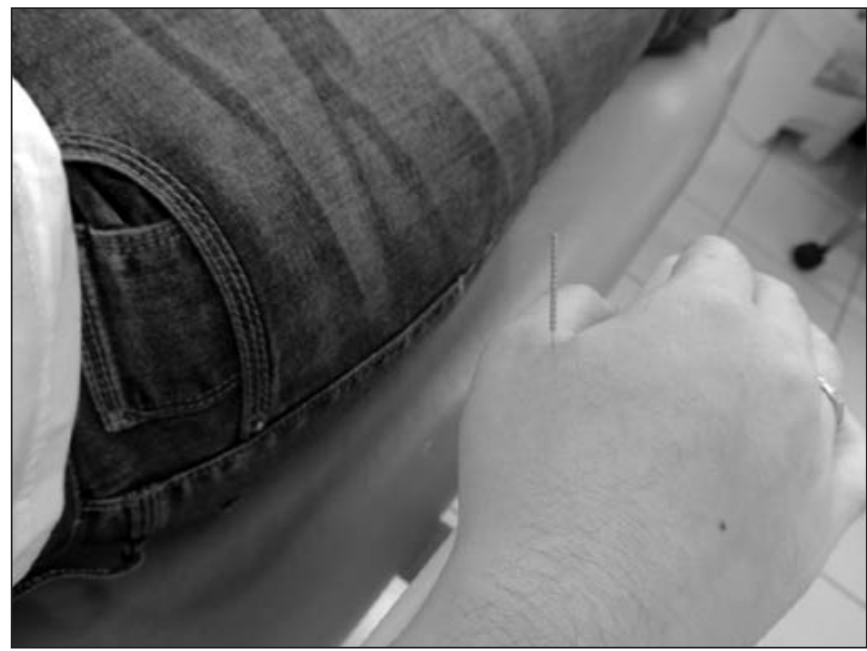

Figure 4. IG4 acupuncture point 


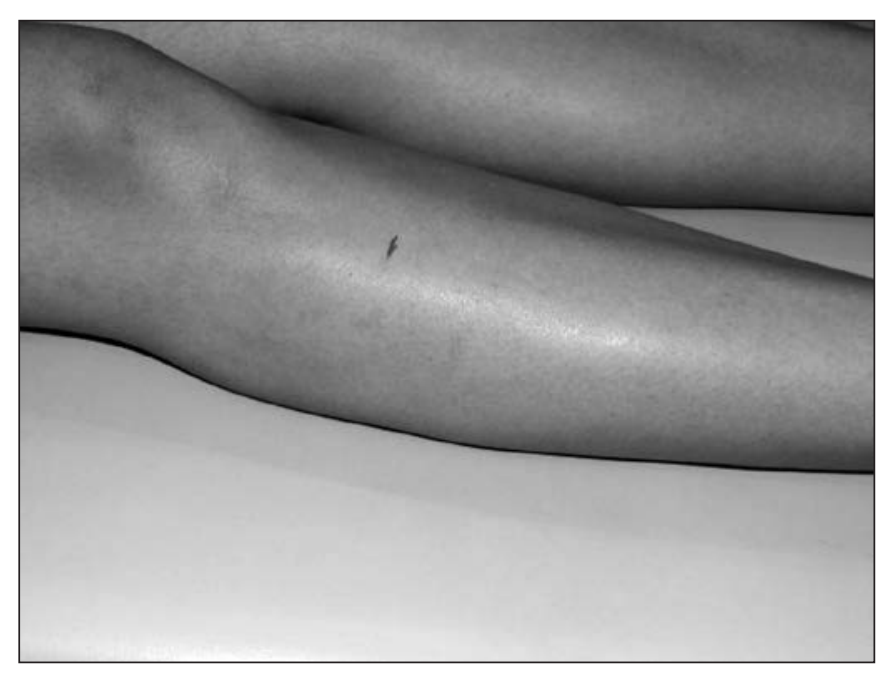

Figure 5. E36 acupuncture point

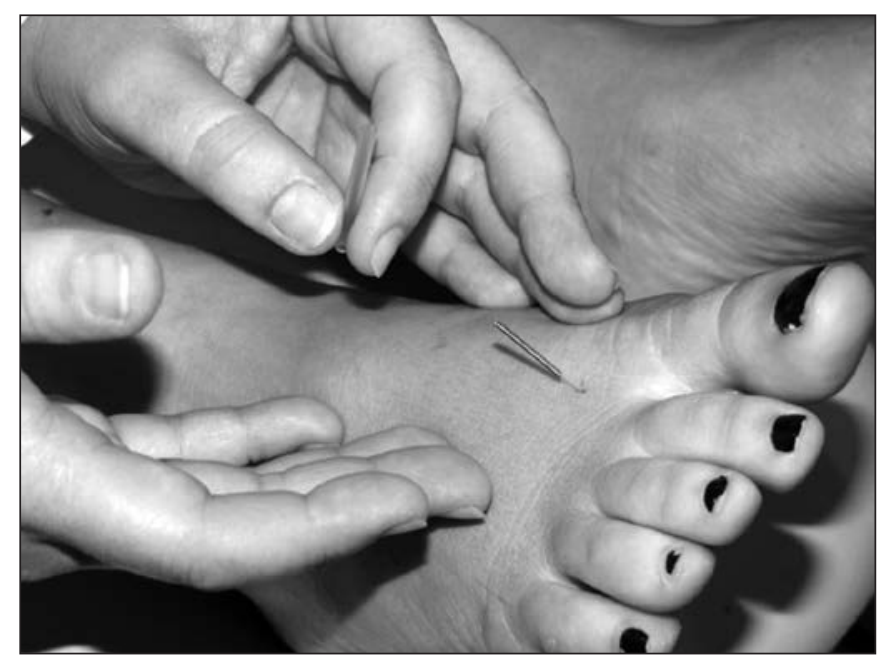

Figure 6. F3 acupuncture point

The visual analog scale (VAS) and the pressure algometer were used to evaluate the pain perception of the volunteers.

The VAS assists in the measurement of pain intensity in the patient to check his/her evolution during treatment and each service, in a practical way. To use the VAS, the researcher must ask the volunteer what his/her degree of pain is, zero means no pain, and 10 the maximum tolerable pain level. The study patients were instructed to mark their pain grade on the day of each evaluation.

The pressure algometer is a device designed to quantify and document sensitivity levels by measuring the pressure threshold and pain sensitivity, measuring tolerance, to check the temporal muscle pain threshold (anterior and middle bundles), and the masseter (medium and inferior fibers).

The patients' mouth opening limitation was evaluated using the caliper before treatment, after 6 weeks of treatment and 4 months after treatment. It is a very accurate tool that measures the distance between two symmetrically opposite sides of an object. In the case of the mouth opening, the reference was the distance between the upper and lower incisors.
The research was approved by the Ethics Committee of the Federal University of Mato Grosso do Sul (CEP/UFMS) CAAE number: 89598418.6.0000.0021.

\section{Statistical analysis}

Data were tabulated in a Microsoft Excel 2010 spreadsheet (Microsoft Corporation, Redmond/Washington/Estados Unidos) and analyzed by the Statistical Package for Social Science Version 18.0 (SPSS Inc., Chicago/Illinois/ Estados Unidos). Initially, descriptive statistics of the collected data were performed using measures of central tendency and dispersion.

In order to verify the association of quantitative variables between G1 and G2, the t-test was used for normal distribution (mouth opening) for independent samples; and for comparison between the evaluation periods (baseline of treatment, after six weeks and 4 months, two by two), the t-test for paired samples was used. For the non-normal distribution (VAS and tension threshold), the Mann-Whitney test was used in the two groups, and for the comparison between the evaluation periods (baseline of treatment, after six weeks and 4 months), the Friedman test was used at a significance level of $5 \%$.

\section{RESULTS}

Table 1 shows the mean and standard deviation of mouth opening measurements at baseline, after 6 weeks and after 4 months of treatment in G1 and G2. G1 was treated with massage, thermotherapy, counseling, and occlusal splint, and G2 underwent acupuncture.

There was no difference in mouth opening measures according to the type of treatment used. However, in both groups (acupuncture and occlusal splint), there was an increase in mouth opening measures after 6 weeks of treatment. There was no difference in mouth opening values after 6 weeks and at the end of treatment after 4 months (Table 1).

Table 2 shows the mean and standard deviation of the VAS scores at baseline, after six weeks of treatment, and at the end, after 4 months of treatment, in both groups.

There was no difference in the VAS scores according to the type of treatment used. However, in both groups (acupuncture and occlusal splint), scores decreased after six weeks of treatment. There was no difference in the VAS scores after six weeks and at the end of treatment after four months (Table 2).

Table 3 shows the mean and standard deviation of the masseter and temporal muscle tension threshold scores at baseline, after six weeks, and at the end of treatment in G1 and G2.

There was no difference in tension threshold scores between G1 (acupuncture) and G2 (occlusal splint), except for the left temporal muscle $(\mathrm{Tb})$, in which the value obtained in G1 (4.7 \pm 1.2$)$ was higher compared to G2 (3.8 \pm 1.6$)$ at evaluation after six weeks of treatment. However, after four months, there was no difference in values.

In the evaluation of the studied period of G1 and G2 separately, there was an increase in tension threshold scores for the evaluated muscles, masseter, and temporal, after six weeks of treatment. However, the values were similar to those obtained after four months (Table 3). 
Table 1. Mean and standard deviation of mouth opening measurements at baseline, after 6 weeks and after 4 months of treatment by type of intervention

\begin{tabular}{|c|c|c|c|c|c|}
\hline \multirow[t]{2}{*}{ Values (mm) } & \multicolumn{2}{|c|}{$\mathrm{G} 1(\mathrm{n}=17)$} & \multicolumn{2}{|c|}{ G2 $(n=17)$} & \multirow[t]{2}{*}{${ }^{(1)} p$-value } \\
\hline & Mean & SD & Mean & SD & \\
\hline \multicolumn{6}{|c|}{ Painless mouth opening } \\
\hline After 6 weeks & b 42.2 & 6.5 & b 44.1 & 5.7 & 0.377 \\
\hline After 4 months & b 41.4 & 7.2 & b 42.9 & 6.6 & 0.539 \\
\hline Baseline & a45.9 & 8.0 & a 44.1 & 6.3 & 0.479 \\
\hline After 6 weeks & b50.4 & 6.6 & ${ }^{b} 51.2$ & 5.3 & 0.692 \\
\hline After 4 months & b49.8 & 6.6 & b50.6 & 7.9 & 0.743 \\
\hline $\mathrm{p}^{(2)}$ & \multicolumn{2}{|c|}{${ }^{(3)} 0.016 ;{ }^{(4)} 0.048 ;{ }^{(5)} 0.704$} & \multicolumn{2}{|c|}{${ }^{(3)}<0.001 ;{ }^{(4)} 0.004 ;{ }^{(5)} 0.639$} & \\
\hline
\end{tabular}

Table 2. Mean and standard deviation of visual analog scale scores at baseline and after 6 weeks of treatment by type of intervention

\begin{tabular}{lccccc}
\hline VAS scores & \multicolumn{2}{c}{$\mathrm{G} 1(\mathrm{n}=17)$} & \multicolumn{2}{c}{$\mathrm{G} 2(\mathrm{n}=17)$} & ${ }^{(1)} \mathrm{p}$-value \\
& Mean & SD & Mean & SD & \\
\hline Baseline & ${ }^{\mathrm{a}} 6.2$ & 2.6 & ${ }^{\mathrm{a}} 5.9$ & 1.7 & 0.679 \\
After 6 weeks & ${ }^{\mathrm{b}} 2.6$ & 2.0 & ${ }^{\mathrm{b}} 1.9$ & 1.5 & 0.459 \\
After 4 months & $\mathrm{b} 1.2$ & 1.1 & $\mathrm{~b} 1.5$ & 1.3 & 0.959 \\
$\mathrm{p}^{(2)}$ & $<0.001$ & $<0.001$ & \\
\hline
\end{tabular}

(1) Mann-Whitney test for independent samples (acupuncture versus occlusal splint); ${ }^{(2)}$ Friedman test for paired samples (baseline versus after 6 weeks of treatment; baseline versus after 4 months of treatment; 6 weeks of treatment versus after 4 months of treatment); different letters indicate statistically significant difference; equal letters indicate statistically not significant difference.

Table 3. Mean and standard deviation of tension threshold scores at baseline, after 6 weeks and after 4 months of treatment according to the type of intervention and muscle evaluated

\begin{tabular}{|c|c|c|c|c|c|}
\hline \multirow[t]{2}{*}{ VAS scores } & \multicolumn{2}{|c|}{$\begin{array}{c}\text { G1 } \\
(n=17)\end{array}$} & \multicolumn{2}{|c|}{$\begin{array}{c}\text { G2 } \\
(n=17)\end{array}$} & \multirow[t]{2}{*}{$\stackrel{(1)}{p \text {-value }}$} \\
\hline & Mean & SD & Mean & SD & \\
\hline \multicolumn{6}{|c|}{ Right masseter muscle (Mc) } \\
\hline Baseline & a 1.8 & 0.9 & a 2.0 & 1.3 & 0.904 \\
\hline After 6 weeks & b 3.2 & 0.8 & b 3.1 & 1.3 & 0.630 \\
\hline After 4 months & b 3.3 & 1.3 & b 3.7 & 2.1 & 0.679 \\
\hline $\mathrm{p}^{(2)}$ & \multicolumn{2}{|c|}{$<0.001$} & \multicolumn{2}{|c|}{0.001} & \\
\hline \multicolumn{6}{|c|}{ Right masseter muscle (Md) } \\
\hline Baseline & a 1.8 & 1.1 & a 2.0 & 0.9 & 0.286 \\
\hline After 6 weeks & b 3.3 & 1.7 & a.b2.8 & 1.2 & 0.294 \\
\hline After 4 months & b 3.0 & 1.0 & b 3.5 & 1.9 & 0.438 \\
\hline $\mathrm{p}^{(2)}$ & \multicolumn{2}{|c|}{$<0.001$} & \multicolumn{2}{|c|}{0.007} & \\
\hline \multicolumn{6}{|c|}{ Left masseter muscle (Mc) } \\
\hline Baseline & a 1.8 & 0.8 & a 1.8 & 0.7 & 0.836 \\
\hline After 6 weeks & b 3.1 & 0.9 & b 3.2 & 1.5 & 0.810 \\
\hline After 4 months & b 3.3 & 1.1 & b 3.5 & 1.6 & 0.959 \\
\hline $\mathrm{p}^{(2)}$ & \multicolumn{2}{|c|}{$<0.001$} & \multicolumn{2}{|c|}{$<0.001$} & \\
\hline
\end{tabular}

Continue...
Table 3. Mean and standard deviation of tension threshold scores at baseline, after 6 weeks and after 4 months of treatment according to the type of intervention and muscle evaluated - continuation

\begin{tabular}{|c|c|c|c|c|c|}
\hline \multirow[t]{2}{*}{ VAS scores } & \multicolumn{2}{|c|}{$\begin{array}{c}\text { G1 } \\
(n=17)\end{array}$} & \multicolumn{2}{|c|}{$\begin{array}{c}\text { G2 } \\
(n=17)\end{array}$} & \multirow[t]{2}{*}{${ }^{(1)}$} \\
\hline & Mean & SD & Mean & SD & \\
\hline \multicolumn{6}{|c|}{ Left masseter muscle $(\mathrm{Md})$} \\
\hline Baseline & a 1.5 & 0.7 & a 1.8 & 0.9 & 0.389 \\
\hline After 6 weeks & b 3.0 & 0.9 & b 3.0 & 1.3 & 0.459 \\
\hline After 4 months & b 3.0 & 1.1 & b 3.5 & 1.7 & 0.491 \\
\hline $\mathrm{p}^{(2)}$ & \multicolumn{2}{|c|}{$<0.001$} & \multicolumn{2}{|c|}{$<0.001$} & \\
\hline \multicolumn{6}{|c|}{ Right temporal muscle (Ta) } \\
\hline Baseline & a 3.1 & 1.0 & a3.3 & 1.1 & 0.796 \\
\hline After 6 weeks & b 5.7 & 1.4 & b5.0 & 1.9 & 0.185 \\
\hline After 4 months & a.b 4.7 & 1.6 & b5.7 & 2.1 & 0.203 \\
\hline $\mathrm{p}^{(2)}$ & \multicolumn{2}{|c|}{$<0.001$} & \multicolumn{2}{|c|}{$<0.001$} & \\
\hline \multicolumn{6}{|c|}{ Right temporal muscle (Tb) } \\
\hline Baseline & a 2.6 & 1.1 & a 2.8 & 1.1 & 0.836 \\
\hline After 6 weeks & b 4.6 & 1.2 & b 4.3 & 2.0 & 0.263 \\
\hline After 4 months & b 3.9 & 1.6 & b 4.6 & 1.8 & 0.163 \\
\hline $\mathrm{p}^{(2)}$ & \multicolumn{2}{|c|}{$<0.001$} & \multicolumn{2}{|c|}{0.001} & \\
\hline \multicolumn{6}{|c|}{ Left temporal muscle (Ta) } \\
\hline Baseline & a 2.8 & 1.1 & a 3.0 & 1.2 & 0.679 \\
\hline After 6 weeks & b 5.1 & 1.2 & b 4.5 & 1.7 & 0.073 \\
\hline After 4 months & b 4.9 & 2.0 & b 5.1 & 1.7 & 0.547 \\
\hline $\mathrm{p}^{(2)}$ & \multicolumn{2}{|c|}{$<0.001$} & \multicolumn{2}{|c|}{$<0.001$} & \\
\hline \multicolumn{6}{|c|}{ Left temporal muscle (Tb) } \\
\hline Baseline & a 2.4 & 1.1 & a 2.5 & 1.2 & 0.960 \\
\hline After 6 weeks & b 4.7 & 1.2 & b 3.8 & 1.6 & 0.040 \\
\hline After 4 months & b 4.0 & 1.8 & b 4.7 & 1.7 & 0.191 \\
\hline $\mathrm{p}^{(2)}$ & \multicolumn{2}{|c|}{$<0.001$} & \multicolumn{2}{|c|}{$<0.001$} & \\
\hline
\end{tabular}

(1) Mann Whitney test for independent samples (acupuncture versus occlusa splint). $\mathrm{p}$-value in bold indicates statistically significant difference; (2)Friedman test for paired samples (baseline versus after 6 weeks of treatment; baseline versus after 4 months of treatment; 6 weeks of treatment versus after 4 months of treatment); different letters indicate statistically significant difference ( $p$ value in bold); equal letters indicate statistically non-significant difference ( $p$ value without bold). 


\section{DISCUSSION}

Pain caused by TMD is musculoskeletal pain that affects deep tissue and, in chronic cases, generates a biopsychosocial process that interferes with patients' normal daily activities ${ }^{26-28}$. Chronic pain should be diagnosed and treated correctly, as TMD pain can significantly compromise the person's quality of life $\mathrm{e}^{29-31}$.

In a randomized clinical study, 40 patients diagnosed with muscle TMD by RDC/TMD were treated. The patients were divided into two groups. One group received placebo treatment, and the other, acupuncture. Patients were evaluated by the VAS to measure pain before and after treatment. The following acupuncture points were selected: E6, E7, ID18 (local points); VB20, VG20, B10 and IG4 (distance points). Patients were treated for four weeks, with sessions lasting 30 minutes each. The patients were reevaluated after 30 days. There was a significant difference between the groups $(\mathrm{p}=0.2261)$, and in the acupuncture group, pain decreased from 5.3 to 1.8 on mean, according to VAS, while in the placebo group, pain remained stable or increased?

Twenty TMD patients were evaluated before treatment, immediately after treatment and 12 months after acupuncture treatment using the VAS. At the initial consultation, an anamnesis was performed according to the TCM standards, and the patient's pain intensity was identified. At the end of treatment of six sessions of 20 minutes each, the patients were reevaluated and after 12 months as well. The means for VAS0, VAS1, and VAS2 were respectively 5.9; 1.65; 2.45. There was a statistical difference between VAS0 and VAS 1 of $\mathrm{p}<0.01$ and between VAS2 $(\mathrm{p}<0.01)$, but there was no difference between VAS1 and VAS ( $>0.05)$. The authors pointed out that the acupuncture treatment reduced pain after six weeks of treatment and remained for a mean of 12 months $^{32,33}$. This study presented results similar to the one conducted at UFMS, as patients showed improvement in pain in the acupuncture group in the 6-week reevaluation and remained in the 4 -month evaluation.

A descriptive study of 31 TMD patients used the VAS before and after treatment to evaluate pain intensity. The patients underwent three acupuncture sessions, 20 minutes each per week. They underwent anamnesis and diagnosis of the TCM, and the selected points were heart channel $\mathrm{C} 7$, pericardial channel PC6, small intestine channel ID3, gallbladder channel VB20, and triple heater channel TA23. The pain ceased $(\mathrm{VAS}=0)$ in $67.7 \%$ of the cases. There was a reduction in pain intensity with VASi of the $1^{\text {st }}$ session $(6.10 \pm 2.64)$ than VASf of the $3^{\text {rd }}$ session $(1.16 \pm 1.98)$. The authors concluded that a minimum of 3 acupuncture sessions is sufficient to reduce pain intensity, regardless of its degree ${ }^{34}$.

In a clinical trial, ten patients with TMD, diagnosed by RDC/TDM, and using the VAS were treated. Patients were randomly divided into two groups, the first group consisting of five patients treated only with physical therapy (massage) for three weeks and the second, also consisting of five patients treated with occlusal splint alone. The study showed that pa- tients who received treatment with physical therapy alone did not reset their pain after treatment; but there was an average decrease of $92.5 \%$ in pain. In patients who received treatment with the occlusal splint, there was a $92 \%$ improvement in the first week, and reset pain until the end of treatment. This showed that the occlusal splint is as efficient as physical therapy treatments ${ }^{15}$.

Acupuncture works to reduce the sensation of pain, and this therapy has been shown effective with conventional TMD treatment techniques ${ }^{35}$. In one study, $20 \mathrm{TMD}$ patients were treated. One group underwent acupuncture associated with occlusal splint, and one group used only the occlusal splint. The acupuncture group was treated with five sessions of 50 minutes each and occlusal splint for night use. The splint group was instructed to use the device only at night. The limitation of mandibular movements before and after treatment was also evaluated. The degree of pain was verified by the VAS. After the first week of treatment, pain and mandibular movements improved in the acupuncture group. After five weeks of treatment, the patients were reevaluated, and there was a significant reduction in the TMD symptoms, but there were no statistical differences between the two groups $(p>0.05)$. However, in the acupuncture group, pain decreased faster ${ }^{13,15}$. Just like these results, the UFMS study showed very similar results.

After a systematic literature review, it was observed that there is no standard protocol for acupuncture for the treatment of TMD, that the choice of acupoints varies according to the degree of patient involvement ${ }^{36}$. Excellent results were obtained using as local points the stomach channel, such as E8; E7, E6; triple heater channel points such as TA21, TA17 and gallbladder channel points such as VB2. These points were used to control local pain. The most frequently applied distance points for the control of anxiety, muscle relaxation, stress reduction, and sleep improvement were the large intestine meridian IG4, stomach E36, triple heater TA5, liver F3, gallbladder VB34, and governing vessel VG20. Based on the literature, Souza e Silva ${ }^{32}$ found evidence of the use of small intestine ID18, stomach E6, E7, governing vessel VG20, gallbladder VB20, bladder B10 points. Other points may also be employed, such as bladder B60 and gallbladder VB3. The authors also emphasize that acupuncture is an excellent treatment method complementary to other therapies, or as a technique of choice for patients with intolerance to occlusal splints ${ }^{18}$.

In a case report of a 32-year-old female patient diagnosed with muscular TMD and evaluated by VAS for pain, an anamnesis of the TCM showed the patient's tongue, pulse, and skin color characteristics.

When evaluating 20 patients who underwent six 30-minute acupuncture sessions, it was observed after six weeks that the pain threshold and muscle tension evaluated by electromyography was statistically better than at baseline and that these improvements remained for 12 months. Similar results were observed in this study, which presented lower VAS index in pain, decreased muscle tension, and improvement in mouth 
opening at 6 weeks and 4 months after treatment in patients undergoing acupuncture with the same number of sessions and treatment time $e^{32,37,38}$.

This action of acupuncture was also found in a study that observed 40 patients treated with acupuncture and after 4 sessions presented decreased pain and lower muscle tension, which was also observed in this study, in which patients were evaluated at 6 weeks and 4 months. It was found that both acupuncture and occlusal splint associated with massage and thermotherapy provided muscle relaxation, improved jaw movements at mouth opening and decreased pain level of patients $^{21}$. These results were similar to the study as patients presented improvement in mouth opening, reduced pain and muscle tension in both acupuncture and splint groups.

In a randomized clinical study of $40 \mathrm{TMD}$ patients diagnosed by RDC/TMD, pain was evaluated by the VAS, and the chewing muscles were evaluated by electromyography before and after treatment. The patients were randomly divided into two groups. The first was treated with acupuncture, underwent anamnesis and diagnosis according to the TCM. The patients were treated with four acupuncture sessions lasting $20 \mathrm{~min}$ utes each. The selected points were: large intestine meridian IG4 and IG11, small intestine meridian ID19, liver meridian F2, bladder meridian B2, conception vessel meridian VC23, triple heater meridian TA23, gallbladder meridian VB21, and VB34. The splint group was treated with a myorelaxant splint, counseling, and self-care guidance. The splints were conventionally made of acrylic and installed and adjusted by a single professional. Patients were instructed to use the splint at night and to return within four weeks. The patients were reevaluated after 30 days of treatment. The electromyography of the masticatory muscles was lower in $40 \%$ in the acupuncture group and $50 \%$ in the splint group. Pain decreased in both groups, but there were no statistical differences between the two. However, in the acupuncture group, pain reduction was faster, and the absence of pain lasted longer. Half of the patients in the acupuncture group had improved mandibular limitations. The authors concluded that acupuncture was as efficient as occlusal splint ${ }^{21}$.

\section{CONCLUSION}

Based on the results of this study, it was concluded that both acupuncture and occlusal splint associated with massage and thermotherapy were effective in treating patients with muscle TMD for six weeks and remained for a period after four months of treatment.

\section{REFERENCES}

1. Abouelhuda AM, Khalifa AK, Kim YK, Hegazy SA. Non-invasive different modalities of treatment for temporomandibular disorders: review of literature. J Korean Assoc Oral Maxillofac Surg. 2018;44(2):43-51.

2. Fonseca Alonso B, Nixdorf DR, Shueb SS, John MT, Law AS, Durham J. Examining the sensitivity and specificity of 2 screening instruments: odontogenic or temporomandibular disorder pain? J Endod. 2017;43(1):36-45.

3. Garbelotti TO, Turci AM, Serigato JMA, Pizzol KE, Franco-Micheloni AL. Effectiveness of acupuncture for temporomandibular disorders and associated symptoms. Rev Dor. 2016;17(3):223-7.
4. Castillo DB, Azato FK, Coelho TK, Pereira PZ, Silva MG. Clinical study on head and jaw position of patients with muscle temporomandibular disorder. Rev Dor. 2016;17(2):88-92

5. Maydana AV, Tesch RS, Denardin OV, Ursi WJ, Dworkin SF. Possible etiological factors in temporomandibular disorders of articular origin with implications for diagnosis and treatment. Dental Press J Orthod. 2010;15(3):78-86.

6. Torres F, Campos LG, Fillipini HF, Weigert KL, Vecchia GF. Efeitos dos tratamentos fisioterapêutico e odontológico em pacientes com disfunção temporomandibular. Fisioter Mov. 2012;25(1):117-25.

7. Grillo CM, Canales Gde L, Wada RS, Alves MC, Barbosa CM, Berzin F, et al. Could acupuncture be useful in the treatment of temporomandibular dysfunction? J Acupunct Meridian Stud. 2015;8(4):192-9.

8. Okeson JP. Tratamento das desordens temporomandibulares e oclusão. $7^{\mathrm{a}}$ ed. Rio de Janeiro: Elsevier; 2013. 101-29p.

9. Zotelli VL, Grillo CM, Gil ML, Wada RS, Sato JE, da Luz Rosário de Souza M. Acupuncture effect on pain, mouthopening limitation and on the energy meridians in patients with temporomandibular dysfunction: a randomized controlled trial. J Acupunct Meridian Stud. 2017;10(5):351-9.

10. Silva HB, Soares JL. Análise da abordagem fisioterapêutica no tratamento da disfunção temporomandibular: revisão integrativa. REAS/EJCH. 2019;19:1-7.

11. Menezes MS, Bussadori SK, Fernandes KP, Biasotto-Gonzalez DA. Correlação entre cefaleia e disfunção temporomandibular. Fisioter Pesqui. 2008;15(2):183-7.

12. Franco AL, Zamperini CA, Salata DC, Silva EC, Albino Júnior W, Camparis CM. Fisioterapia no tratamento da dor orofacial de pacientes com disfunçăo temporomandibular crônica. Rev CubanaEstomatol. 2011;48(1):56-61.

13. Furlan RM, Giolvanardi RS, Britto AT, Britto DB. O emprego do calor superficial para tratamento das disfunçóes temporomandibulares: uma revisão integrativa.CoDAS. 2015a;27(2):207-12.

14. Furlan RM. O uso da crioterapia no tratamento da disfunção temporomandibular. Ver Cefac. 2015b;17(2):648-55.

15. Ferreira FM, Simamoto-Júnior PC, Soares CJ, Ramos AM, Fernandes-Neto. Effect of occlusal splints on the stress distribution on the temporomandibular joint disc. Braz Dent J. 2017;28(3):324-9.

16. Florian MR, Meirelles MP, Souza ML. Disfunção temporomandibular e acupuntura: uma terapia integrativa e complementar. Odontol Clín Cient. 2011;10(2);189-92.

17. Bontempo GG, Melo PB, Pizzol KE, Franco-Micheloni AL. Ear acupuncture associated to home self-care in the treatment of chronic temporomandibular disorders in women. Case report. Rev Dor. 2016;17(3):236-40.

18. Boscaine EF, Suliano LS, Pontes ER, Castillo DB, Moraes JL, Nascimento VA. Effects of acupuncture in the treatment of temporomandibular dysfunctions. Int J Develop Res. 2018;8(3):19294-7.

19. Brahim CB, Araújo JO, Queiroz DA, Dessaune Neto N, Tinelli D, Cury SE. Eficácia da técnica de agulhamento seco no controle da síndrome da dor miofascial: uma revisão crítica da literatura. Cadernos UniFOA, Volta Redonda. 2017(34):105-24.

20. Borin GS, Corrêa EC, Silva AM, Milanesi JM. Surface electromyography of masticatory muscles in individuals with temporomandibular disorder submitted to acupuncture. Rev Soc Bras Fonoaudiol. 2012;17(1):1-8.

21. Pereira MS, Silva BO, Santos FR. Acupuntura: terapia alternativa, integrativa e complementar na odontologia. R CROMG. 2015;19(1):19-26.

22. Shueb SS, Nixdorf DR, John MT, Alonso MT, Durham J. "What is the impact of acute and chronic orofacial pain on quality of life"? J Dent. 2015;43(10):1203-10.

23. Costa A, Bavaresco CS, Grossmann E. The use of acupuncture versus dry needling in the treatment of myofascial temporomandibular dysfunction. Rev Dor. 2017;18(4):342-9

24. Luiz AB, Babinski MA, Ferreira AS. Neurobiologia da analgesia induzida por acupuntura. Manual e eletroacupuntura: revisăo de literatura. J Naturol Compl Ther. 2012;1(1):71-84.

25. Maciocia G. Os Fundamentos da Medicina Chinesa. 2a ed. São Paulo: Roca;2014. 3-14p.

26. Porporatti AL, Costa YM, Stuginski-Barbosa J, Bonjardim LR, Conti PC. Acupuncture therapeutic protocols for the management of temporomandibular disorders. Rev Dor. 2015;16(1):53-9.

27. Ahmed NA, Poate T, Nacher-Garcia C, Pugh N, Cowgill H, Page L, et al. Temporomandibular joint multidisciplinar team clinic. Br J Oral Maxillofac Surg.2014;52(9):827-30

28. Boleta-Ceranto DC, Alves T, Alende FL. O efeito da acupuntura no controle da dor na odontologia. Arq Ciênc Saúde Unipar, Umuarama (PR). 2008;12(2):143-8

29. Catão MH, Oliveira PS, Costa RO, Carneiro VS. Evaluation of the efficacy of low-level laser therapy (LLLT) in the treatment of temporomandibular disorders: a randomized clinical trial. Ver Cefac. 2013;15(6):1601-8.

30. Wang B. Princípio de Medicina Interna do Imperador Amarelo. São Paulo: Ícone; 2013. 21-34p

31. Menezes MS, Bussadori SK, Fernandes KP, Biasotto-Gonzalez DA. Correlação entre cefaleia e disfunção temporomandibular. Fisioter Pesqui. 2008;15(2):183-7.

32. Souza LM, Silva IC. A utilizaçấo da acupuntura no tratamento da disfunçấo da articulaçăo temporomandibular: sugestão para protocolo clínico. Acta de Ciências e Saúde. 2016;5(2):112-28

33. Souza ML, Mashuda CS, Sato JE, Siqueira JT. Effect of acupuncture in adults with temporomandibular disorders. Rev Dor. 2014;15(2):87-90.

34. Camargo BA, Grillo CM, Souza ML. Temporomandibular disorder pain improvement with acupuncture: preliminary longitudinal descriptive study. Rev Dor. 2014;15(3):159-62. 
35. Ferreira LA, Grossmann E, Januzzi E, Gonçalves RT, Mares FA, de Paula MV, et al. Ear acupuncture therapy for masticatory myofascial and temporomandibular pain: a controlled clinical trial. Evid Based Complement Alternat Med. 2015;2015;342507.

36. Zotelli VL, Meirelles MP, Souza ML. Uso da acupuntura no manejo da dor em pacientes com alteraçōes na articulação temporomandibular (ATM). Rev Odontol Univ Sấo Paulo. 2010;22(2):185-8.
37. Vicente-Barrero M, Yu-Lu SL, Zhang B, Bocanegra-Pérez S, Durán-Moreno D, López-Márquez A, et al. The efficacy of acupuncture and decompression splints in the treatment of temporomandibular joint pain-dysfunction syndrome. Med Oral Patol Oral Cir Bucal. 2012;17(6):e1028-33.

38. Vera RMT, Grillo CM, Fortinguerra ML, Souza ML, Berzin F. Acupuncture to manage orofacial pain and tinnitus. Case report. Rev Dor. 2013:14(3):226-30. 